\title{
The Implementation of School Based Management in MTs. Islamiyah Ypi Batang Kuis
}

\author{
Adlin Damanik ${ }^{1}$, Ahmad Husin Siregar ${ }^{2}$ \\ 1.2Faculty of Tarbiyah and Teacher Training, Universitas Islam Negeri Sumatera Utara, Indonesia \\ Email: adlindamanik@uinsu.ac.id
}

\begin{abstract}
This study aims to reveal how the pattern of implementation of school-based management (SBM) in Islamic MTs YPI Batang Quiz. This research uses a qualitative approach. Or collected from informants who are selected in a strict way. Research data were collected by interview, observation and documentation study techniques. Data were analyzed using the miles and Hubberman steps. The results of the study revealed that: Planning and implementing patterns of implementation of school-based management (SBM) in MTS YPI Batang Quiz has been relatively running well according to the format of school-based management. While the obstacles faced are not significant and can be resolved properly.

Keywords: pattern; application of school-based management
\end{abstract}

\section{Introduction}

Education is a universal human need for all human beings wherever and whenever. In Indonesia education is the need of all citizens, because education is a means of strategy to improve the quality of a nation. In essence, education is aimed at humanizing humans, changing human behavior maturity and improving human quality for the better so that it is able to challenge the ever changing times. Therefore the progress of a nation can be marked and measured by the progress of its education, because the progress of several countries in the world is started and achieved from education.

School organization design is in which there is a school administration team consisting of a group of people who work together in order to achieve organizational goals. SBM was born with several different names, namely school-based governance (School-basedmanagement), school self-management, and even also known as school site management or management based in schools. School Based Management (SBM) is needed to create a new paradigm in education and in addition it also requires a precise strategy in the application of SBM which is expected to be able to solve problems regarding the needs in management of education so that its quality is better.

To create quality education, schools are expected to be able to create patterns of application of the SBM program to the maximum extent possible. In order to create a maximum pattern of implementing SBM programs, schools must meet National Education Standards. Based on the explanation above, the pattern of implementing the SBM program has been carried out by all education units including all MTs in the Deli Serdang area, both public and private MTs. BAN-SM can be reviewed which MTs have implemented the SBM program implementation patterns to the maximum by looking at the application of each Education Unit. Based on the background of the problem that has been stated above, several main issues can be drawn for analysis and analysis in this paper. The main issues are: 1. Planning Pattern for School-Based Management Implementation, 2. Implementation of School-Based Management Application Patterns, 3. Obstacles to the Implementation of School-Based Management Patterns, and 4. School-Based Supervision in MTs Islamiyah YPI Batang Quiz. 


\section{Review of Literatures}

\subsection{Management}

Management literally, comes from the Latin language, "Manus" which means "Hand" which means "do, carry out, manage, direct and empower". We can mean for a while that management is doing it by hand, power or power.

Planning is known as "the base function" or the basic function of management, because this function is the basis for the implementation of other functions. Planning is the most important initial part of a work. We understand that "the beginning is the most important part of the work" (Suparlan: 2013:41).

This management function is known as the subsequent function. This organizing function is mainly related to the human component (man). However, related to financial components and other resources. For example, harmonious relations between employees, teachers, and administrative staff will play an important role in improving organizational performance. (Nasrul, 2011:36).

Staff or employees must understand the vision and mission of the organization, and have a high commitment to carry out the main tasks and functions to achieve organizational goals. At the level of school education units, teachers and school administrators must work together in synergy to improve the quality of education in schools according to their main tasks and functions each.

Implementation or Actuating, namely the process of implementing the program to be carried out by all parties in the organization and the process of motivating so that all parties can carry out their responsibilities with full awareness and high productivity. Of all the management process sequences, actuating is the most important management function. In the planning and organizing function is more related to the absent aspects of the management process, while the actuating function actually emphasizes more on activities directly related to people in the organization.

In this case, actuating is an effort to move the group members in such a way that they wish and try to achieve the company's goals because the members also want to achieve these goals. (Amiruddin, 2012:109).

From the above understanding, implementation or actuating is nothing but an effort to make planning a reality, through various directives and motivations so that each employee can carry out optimal activities in accordance with their roles, duties and responsibilities.

Controlling (controlling), is the last action taken by managers in an organization. Siagian (1985) argues that controlling (controlling) is a process of observation or monitoring of the implementation of organizational activities to ensure that all work being carried out goes according to a predetermined plan.

With supervision it is expected that irregularities in various things can be avoided so that goals can be achieved. What is planned is carried out correctly according to the results of deliberations and the utilization of material resources will support the realization of organizational goals (Abudi Nata: 2003:120). 
Process of supervision that will guarantee a standard for achieving goals. As explained by Terry, "Controlling is determining, what is being accomplished, that evaluating performance and, if necessary applying corrective measures so performance takes according to plans". The above explanation can mean that supervision is a systematic effort to determine what has been achieved that leads to performance appraisal and the importance of correcting or measuring performance based on predetermined plans.

Oversight made in the management function is actually a strategy to avoid deviations in terms of a rational approach to the existence of input (the amount and quality of materials, money, staff, equipment, facilities and information), as well as supervision of activities (scheduling and implementation of organizational activities), while the other is supervision of output (desired product standards).

\subsection{School-Based Management}

School Based Management can be interpreted as a management model that gives autonomy (greater authority and responsibility to the principal), gives flexibility / flexibility to the school, encourages direct participation from the school community (teachers, students, principals, employees) and the community (parents, community leaders, scientists, business people), and improving the quality of schools based on national education policies and applicable laws and regulations. (Suparlan; 2013:47).

Then Borrowing an opinion is concerned that school-based management ( $\mathrm{SBM}$ ) is basically a management system where the school is an important decision-making unit regarding the delivery of education independently. SBM provides the opportunity for greater control for principals, teachers, students, and parents over the education process in their schools.

In this approach, certain decision-making responsibilities regarding the budget, staffing, and curriculum are placed at the school level and not the local level, let alone the center. Through the involvement of teachers, parents, and other community members in these important decisions, SBM is seen as creating an effective learning environment for students. Thus, basically SBM is an effort to make schools independent by empowering them (Syilviana, 2010:160)

School-Based management is the decentralization and autonomy of the operation and implementation of learning decisions for school principals in education. The terms autonomy and decision-making are autonomy and decision-making which have certain limits, not full autonomy and decision-making.

So, as described above, education and learning for every citizen is one of the tasks of the State ordered by the opening of the 1945 Constitution, which is operationally ordered by Article 31 of the 1945 Constitution, which is then elaborated by the National Education System Law and its implementing regulations.

Therefore, schools must operate within the framework of national education policies determined by the central government. For example, schools must follow the national Education Standards determined by the Ministry of National Education.School Based Management (SBM) is a word equivalent of School-Based Management (SBM). In this case Bang the world (The World Bank) has provided that understanding. "School-Based 
Management is the decentralization of authority to the school level. Responsibility and decision-making over school operations is transferred to principals, teachers, parents, sometimes students, and other school community members. The school-level actors, however, have to conform, or operate, within a set of centrally determined policies.

In strategic planning, we must always do an analysis of the strengths that we have (strengths), weaknesses (weaknesses), opportunities (opportunities) and threats that may occur in the process of planning, organizing, and implementing it.

In the Indonesian context, school-based management aims to make schools more independent or empower schools through giving authority (autonomy), greater flexibility to schools in managing resources and encouraging school community participation and community to improve the quality of education.

\section{Research Methods}

This research uses a descriptive qualitative approach. The qualitative descriptive approach used in this research is in the form of case studies. This qualitative case study format focuses on a particular unit of various phenomena. (M. Buhan Bungin; 2011:68). This research was conducted at MTs. Islamiyah YPI Deli Serdang Deli Serdang Regency. The research data collected were in the form of information about implementing the SBM implementation patterns in MTs. Islamiyah YPI Deli Serdang, and the role of stakeholders in developing the curriculum itself.

This research data was collected from various sources which included: 1) Informants or resource persons, namely school principals, teachers, students, and parents in MTs. Islamiyah Deli Serdang. 2) Documents and files that can be related to the object of research. 3) As well as the place and event of the ongoing interaction between education staff and the learning process.

The procedure of collecting research data uses two types of data, which can be classified as follows: 1) Primary Data, the primary data referred to includes data obtained from the results of interviews with schools and MTs stakeholders. Islamiyah YPI Deli Serdang and the results of observations. 2) Secondary Data, secondary data used in this study are data obtained through library research. Research data collection is done by means of observation, interviews, and documentary studies. In this research, we used Milles and Huberman's analysis which consisted of: (a) data reduction, (b) data presentation, and (c) conclusion.

\section{Discussion}

\subsection{School Based Management Planning in MTs Islamiyah YPI Batang Quiz}

School Based Management (SBM) is basically a management system where the school is an important decision-making unit regarding the implementation of education independently, both in terms of curriculum, facilities and infrastructure, education management, financing and student graduation competencies.

In school-based planning, the pattern of implementing SBM madrasah head and other personnel need to have leadership knowledge, knowledge as a supervisor, administrator, ability to manage and so on as well as having a broad view and knowing the ins and outs of madrasah. 
The results of the interviews obtained in the field with the madrasah headmaster MTs Islamiyah YPI Batang Quiz is that researchers can explain the results of research on schoolbased management planning in MTs Islamiyah YPI Batang Quiz. This is in accordance with the results of an interview with the madrasah head of MTs Islamiyah YPI Batang Quiz on March 16, 2016 at 09.20 WIB, he revealed that: "plan in SBM is basically the implication of management functions found in school-based management. So in the planning, we usually plan school programs during the teaching and learning process, besides that the madrasa has been able to collect the overall plan to be addressed in order to obtain maximum results so that the madrasa can improve the quality and quality of various aspects of madrasa.

This can be started from selecting or determining the education and education staff who will manage the educational process in the madrasa. Educators and educational staff are professionals in their fields and are able to take responsibility for their respective duties. Other than that, the way with the statement of the madrasah head above about the School Based Management plan obtained in an interview with the Deputy Head of Madrasah MTs Islamiyah Ypi Batang Quiz, described as follows: "With the Madrasah Based Management Planning, all activities carried out will feel easier and run effectively because there are targets to be achieved. In the planning, it must have qualified personnel in their fields and involve all teachers and staff in providing opinions or proposals that occur to be decided deliberately, everything planned has proceeded smoothly and has almost reached 75\%".

From the results of the two interviews, that Madrasah-Based Management Planning, must have qualified personnel, experts and professionals in their fields and be able to improve the quality of madrasas.

\subsection{Implementation of School Based Management in MTs Islamiyah YPI Batang Quiz}

The implementation is a management function in the form of real work activities in a management activity, which is also the fruit of a plan that becomes a concrete action in order to achieve the goals set previously.

The following is the result of an interview with the madrasa head about the implementation of the school-based management plan at MTs Islamiyah YPI Batang Quiz on March 16, 2016 at 09.35 WIB, he revealed: "The implementation of the school-based plan that we are doing has gone well, one form of implementation is to carry out the personality of students, let students shape their character with the capabilities they have by organizing in madrasah, so far the implementation has been said to be good from year to year".

In addition, the madrasah head also added that the results achieved in the implementation of SBM had been implemented at MTs Islmaiyah YPI Batang Quiz, he revealed as follows: "In the implementation of SBM, it was realized that this madrasa had advantages and disadvantages, but these deficiencies were strived to like madrasa educators seeking to improve the quality of teachers with education and training, workshop and others, fostering a sense of competition but only to increase self towards a better, and foster competition between teachers to do their best, and also in the field of learning, madrasas seek to increase student power and interest with a fun learning system, foster a sense of sincerity as a teacher and a sense of sincerity as students during the learning process, and improve student achievement both at the regional level and even at the national level".

From some of the explanations above, it can be seen that the implementation of the 
School Based Management plan has been going very well. Implementation of School-Based plans is an effort to make planning a reality, through various influences and motivations so that every educator and educational staff can carry out activities optimally in accordance with their roles, tasks and responsibilities.

From the results of the interview above shows that the Implementation of School Based Plans is already running and in accordance with the program, it can be seen from the support of the madrasa head and educators and educators who are always trying to try their best for this madrasa. Madrasah principals always contribute very well in supporting schoolbased implementation. It can be seen from the headmaster of madrasas as well as educators and education staff always striving for a learning system that is always improving, fulfilling facilities and infrastructure in order to uphold the quality of education of students.

\subsection{Obstacles in the implementation of School Based Management in MTs Islamiyah YPI Batang Quiz}

Obstacles in every activity are certain, especially if a leader does not really understand the meaning of SBM itself, obstacles can sometimes arise from the leaders themselves, can also be from subordinates and even from infrastructure facilities in schools that may not yet support for implementation planning activities This School Based Management.

"In implementing SBM in schools the problems faced are basically not very significant. But indeed, in SBM, the management of which involves all school members and school stakeholders requires extra thought and process. Because we have to unite all opinions in formulating school programs ".

"The problem faced in planning the implementation of school-based management is basically not too serious, sometimes the problem comes from our own, meaning that here the lack of awareness of school personnel to work together, while to realize and implement this SBM requires cooperation with other school members so that achievement of goals that have been implemented together, so actually the problem is not too serious, can still be solved together, and sometimes this is often discussed during teacher meetings, so the problem will eventually be completed and the achievement of the goals that have been planned for madrasas in the future ".

From the results of the interviews and explanations above we can see that the obstacles that occurred in the implementation of SBM in MTs Islamiyah YPI Batang Quiz are not too significant, even can be resolved easily.

Based on the results of interviews, observations and documentation conducted by researchers that the headmaster of MTs Islamiyah YPI Batang Quiz has carried out his duties as a madrasa supervisor to uphold educational performance and educators so that teaching and learning programs can be implemented properly.

\subsection{School Based Supervision in MTs Islamiyah YPI Batang Quiz}

School-based supervision in the pattern of implementation (SBM) in schools can be said that all organizational activities are carried out as planned and implemented well. However, improvements will still be made to repair the dam if there are deviations that will disrupt the achievement of the goals set. 
Supervision is in the form of direct and indirect supervision, but I mostly conduct direct supervision, such as when I do class visits when the learning process is taking place, I do this to find out clearly whether they educators perform their duties responsibly as educators. "From the process of supervision we, as a school, do supervise the implementation of SBM in schools, school students conduct direct supervision in class as supervisors, and sometimes if the headmaster is busy I substitute to supervise in the classroom the teachers who are teaching."

From the results of the two interviews above it is clear that in the Madrasah conducted supervision in the application of School Based Management, and added to the explanation of a teacher obtained from the interview results as follows: "Supervision carried out by the principal is carried out directly in other words the principal conducts supervision at school directly plunges in the classroom when learning takes place because I once during the learning process the principal participate in the class seeing the learning done in class"

From the interviews and explanations above, it can be seen that in the school the headmaster has conducted good supervision, which includes class visit supervisors, classroom supervisors and subjects. In other words that supervision at the MTs Islamiyah YPI Batang Quiz School has been going well in accordance with what was planned beforehand.

Planning is the most important initial part in the management of the objectives to be achieved by an organization must go through an early planning stage, so that an activity can run smoothly, and based on this in the findings of this study shows that school-based management planning in MTs Islamiyah YPI Batang Quiz has been went well, and everything could not be separated from the role of the school principal, deputy headmaster and also the teaching staff at MTs Islamiyah YPI Batang Quiz which was as a special expert team at the school. And in the planning carried out in the form of short-term, long-term and long-term planning in the pattern of applying school-based management. Based on the description of observational data, interviews and documentation studies it can be concluded that in schoolbased management planning is planned as well as possible.

School-Based Management is widely applied in schools, not only in developed countries but also in developing countries, the application of SBM has promised to improve education quality. The implementation of SBM will succeed if given preconditions by building school capacity and commitment, based on what is done in the implementation of SBM in MTs Islamiyah YPI Batang School Quiz, vice-principal and also the MTs Islamiyah YPI Batang Kuis teacher staff are equally responsible and work together in implementing SBM in schools well, applications such as carrying out student personality, letting students shape their character with the capabilities they have by organizing in madrasas, and so far the implementation of SBM in MTs Islamiyah YPI Batang Quiz has been going quite well.

In an organization such as a school, a problem always exists, meaning that a problem cannot be avoided, but if there is a problem that is an obstacle in an activity, it is resolved quickly, as in the pattern of implementing SBM in MTs Islamiyah YPI Batang Quiz have obstacles in their implementation such as those found in the middle of educators that sometimes the staff of teachers are lacking in carrying out the tasks assigned so as to improve it makes time increases and the lack of supporting infrastructure to carry out these activities.

Oversight is often referred to as control which is one of the management functions in the form of conducting assessments, if necessary to carry out corrections so that what is done by subordinates can be directed to the correct path with the intentions of the objectives 
outlined earlier, and according to this in MTs Islamiyah YPI Batang Quiz also school authorities monitor the pattern of implementation of SBM with the aim also that if an error occurs can be as quickly as possible repaired.

\section{Conclusion}

Based on the description and discussion of the results of research on the implementation of school-based management in MTs Yapim Batang Quiz that:

1. Planning in the pattern of applying school-based management in MTs Islamiyah YPI Batang Quiz has been going well, in other words that this SBM planning has improved from year to year starting from student independence, starting to improve the character and pattern of student independence, basically the student's character and student independence. , the pattern has been in many forms such as entrepreneurship, organizational development, and organizational management in the madrasa has been running well managed by the students themselves, the madrasa head who directs and conducts and puts things first is more important ".So the conclusion drawn about School Based Planning in MTs Islamiyah can be that the efforts of the headmaster and educators as well as education staff in the pattern of applying school-based management in MTs Islmiyah YPI Batang Quiz have been carried out to the maximum extent possible in accordance with the ability of madrasas.

2. School-Based management that has been done has gone well, one form of implementation is to run the personality of students, let students shape their character with the capabilities they have by organizing in madrasas, so far the implementation has been said to be good from year to year.

3. From the results of research that there are some obstacles in implementing SBM in schools that become obstacles in the implementation of SBM in MTs Islamiyah YPI Batang Quiz such as the lack of cohesiveness between teachers in carrying out their tasks, also the lack of targeted facilities that support the success of SBM expectations, but the madrasas are not only silent but the madrasa continues to look for solutions always to overcome these obstacles.

4. The interview clearly revealed that the supervision efforts carried out by the madrasa were indeed carried out by the madrasa both the school and the teaching staff. And supervision carried out in madrassas is that the madrasa head has been supervising well, which includes class visit supervisors, classroom supervisors and subjects supervisors. 


\section{References}

Abudi., Nata. 2003. Manajemen Pendidikan Islam. Jakarta: Kencana.

Ananda, R., Samsuddin. 2019. Communication of School Heads in Improving Education Performance in SMA Plus Private Vocational School, Al-Azhar Medan. Britain International of Linguistics, Arts and EducationSciences (BIoLAE) Journal (1): 8-15.

Bafadal, I. 2005. Manajemen Peningkatan Mutu Sekolah Dasar, Jakaerta : Bumi Aksara.

Bunging, M B. 2011. Penelitian Kualitatif. Jakarta: Kencana.

Muhaimin, 2011. Manajemen Pendidikan Aplikasinya Rencana Penyusunan Rencana Pengembangan Sekolah, Jakarta : Kencana

Mulyasa. 2009. Manajemen Berbasis Sekolah. Bandung: Pt Remaja Rosdakarya.

Njega, S. W., Njoka, J. N., Ndung'u, C. W. 2020. Influence of School Conduciveness on Learners' Academic Performance in Public Secondary Schools in Murang'a and Kirinyaga Counties in Kenya. Britain International of Linguistics, Arts and Education (BIoLAE) Journal (2): 362-377.

Salim., Syahrum. 2007. Metodologi Penelitian Kualitatif, Bandung: Cipta Pustaka. Siahaan, A. 2012. Administrasi Satuan Pendidikan, Medan : Perdana Publshing. Siahaan, S. P. 2007. Manajemen Strategik, Jakarta : Bumi Aksara.

Suparlan. 2013. Manajemen Berbasis Sekolah, Jakarta : Bumi Aksara.

Suryosubroto. 2010. Manajemen Pendidikan di Sekolah, Jakarta : Rineka Cipta,2010

Syilviana. 2010. Manajemen dan Organisasi, Jakarta : Raja Grafindo Prsada. 